\title{
FAKTOR-FAKTOR YANG BERHUBUNGAN DENGAN REAKSI NYERI AKIBAT TINDAKAN INVASIF PADA ANAK YANG DIRAWAT
}

Metha Kemala Rahayu ${ }^{1}$, Fajar Tri Waluyanti ${ }^{2}$, Happy Hayati ${ }^{3}$

1 Dosen Akper Hermina Manggala Husada, Jakarta

2,3 Fakultas IImu Keperawatan, Universitas Indonesia, Depok 16424, Indonesia

\begin{abstract}
Abstrak
Tindakan invasif yang didapat anak selama dirawat menimbulkan reaksi nyeri. Perawat perlu mengetahui faktor-faktor yang berhubungan dengan reaksi nyeri. Penelitian ini bertujuan untuk mengidentifikasi faktor-faktor yang berhubungan dengan reaksi nyeri akibat tindakan invasif. Desain penelitian adalah penelitian observasional dengan pendekatan cross sectional dengan teknik pengambilan sampel dilakukan secara non probability sampling melalui consecutive sampling dengan jumlah responden sebanyak 90 orang. Analisa data multivariat menggunakan uji statistik regresi multinomial. Hasil analisis menunjukkan terdapat hubungan yang signifikan antara ketakutan dengan reaksi nyeri ( $p$ value $=0,018$ ). Anak yang takut memiliki peluang 5 kali untuk terjadinya reaksi nyeri kategori menghindar dibandingkan anak yang tidak takut. Perawat perlu melakukan intervensi keperawatan yang dapat mengurangi ketakutan pada anak sehingga reaksi nyeri kategori menghindar dapat diminimalkan.
\end{abstract}

Kata kunci: reaksi nyeri, tindakan invasif, ketakutan, anak

\begin{abstract}
Invasive treatments to the children during the period of hospitalization cause pain reactions. The nurses need to know the factors related to pain reactions. The study aims to identify the factors related with pain reactions related to invasive treatments. The design of this study is observational research with cross sectional approach by using non probability sampling method through consecutive sampling with the amount of 90 children respondents. Multivariate data analysis use multinomial regression statistic test. The result of the analysis indicated that there was a significant relationship between fear and pain reaction ( $p$ value $=0,018$ ). The emergence of pain reaction "avoidance" from the children who are in fear is as much 5 times greater than children who are not in fear. Nurses need to conduct nursing interventions that can reduce fear in the children behavior in order to minimize pain reaction in form of avoidance.
\end{abstract}

Keywords: pain reaction, invasive treatments, fear, children 


\section{Pendahuluan}

Tindakan invasif yang didapat anak selama dirawat di rumah sakit akan menyebabkan trauma akibat nyeri yang dirasakan. Seorang perawat bertanggung jawab sedapat mungkin untuk menghilangkan atau mengurangi rasa nyeri pada klien anak (American Academy of Pediatrics/American Pain Society, 2002; Morton, 2008; Czarnecki et al., 2011). Untuk mengurangi rasa nyeri pada anak, perawat harus melakukan pengkajian nyeri termasuk mengetahui faktor-faktor yang berhubungan dengan reaksi nyeri.

Faktor-faktor yang berhubungan dengan reaksi nyeri yaitu faktor internal meliputi jenis kelamin, usia, temperamen, ketakutan, dan pengalaman nyeri sebelumnya serta faktor eksternal meliputi tindakan invasif, paparan nyeri sebelumnya, budaya, dan kehadiran keluarga selain orang tua (Le Mone \& Burke, 2008; Czarnecki et al. 2011).

Reaksi nyeri anak usia prasekolah seperti menangis, berteriak, ekspresi verbal seperti "aduh", "aoww", "sakit", memukul-mukulkan lengan dan kaki, tidak kooperatif, meminta dukungan emosional seperti pelukan (Hockenberry \& Wilson, 2009). Reaksi nyeri anak usia sekolah seperti menggigit bibir atau memegang sesuatu dengan erat (Supartini, 2004).
Tindakan invasif yang paling banyak dilakukan pada anak di RSUD Kota Bekasi adalah pengambilan darah melalui vena dan pemasangan kateter intravena. Di RSUD Kota Bekasi, perawat tidak melakukan pengkajian nyeri pada setiap anak yang dirawat. Tindakan invasif yang dilakukan menyebabkan timbulnya reaksi nyeri.

\section{Metode}

Desain yang digunakan dalam penelitian ini adalah cross sectional. Kriteria inklusi sampel penelitian ini adalah klien anak usia 3-7 tahun dan akan dilakukan tindakan invasif serta telah dirawat di rumah sakit minimal 2 hari. Jumlah sampel pada penelitian ini adalah 90 orang anak. Tempat penelitian adalah di RSUD Kota Bekasi. Penelitian telah dilaksananakan pada bulan Februari 2015Juni 2015.

Instrumen yang digunakan pada penelitian ini adalah kuesioner terdiri dari kuesioner demografi berisi data usia, jenis kelamin, pengalaman nyeri sebelumnya, paparan nyeri sebelumnya, suku bangsa, dan kehadiran keluarga selain orang tua serta kuesioner temperamen. Lembar observasi terdiri dari lembar observasi respon ketakutan anak dan lembar observasi reaksi nyeri anak prasekolah dan sekolah. Lembar observasi yang dibuat sendiri oleh peneliti adalah lembar observasi reaksi nyeri yang telah 
melalui uji reliabilitas dengan hasil uji Kappa bermakna $(r=0,600)$.

Prosedur pada penelitian ini dimulai dengan peneliti melakukan sosialisasi singkat kepada perawat primer dan perawat pelaksana tentang maksud dan tujuan penelitian, peneliti melakukan uji interrater reliability untuk menguji reliabilitas instrumen lembar observasi reaksi nyeri melalui uji Kappa untuk menentukan perawat yang terpilih menjadi asisten peneliti.

Peneliti menjelaskan instrumen yang harus diisi orang tua yaitu kuesioner demografi dan

\section{Hasil}

Sebagian besar usia responden adalah prasekolah (53,3\%), berjenis kelamin laki-laki (53,3\%), pernah mengalami nyeri sebelumnya $(82,2 \%)$, dan memiliki tipe temperamen lambat memanas (76,7\%). Jumlah responden yang takut (45\%) sama banyak dengan jumlah responden yang tidak takut (45\%).

Sebagian besar responden belum pernah terpapar nyeri sebelumnya (68,9\%). Tindakan invasif yang paling banyak dilakukan adalah pemberian obat injeksi (52,2\%). Mayoritas suku bangsa yang dimiliki responden adalah suku Jawa (41,1\%). Sebagian besar responden didampingi keluarga selain orang tua $(55,6 \%)$. Reaksi nyeri kategori emosi dan kuesioner temperamen anak; peneliti meminta perawat primer untuk mengisi jenis tindakan invasif yang dilakukan dan mengisi lembar observasi ketakutan 5 menit sebelum tindakan invasif dilakukan; perawat pelaksana membantu peneliti melakukan observasi melalui perekaman video reaksi nyeri; asisten terpilih mengisi lembar observasi reaksi nyeri sesuai usia anak. Analisis data meliputi analisis univariat, analisis bivariat, dan analisis multivariat menggunakan uji regresi multinomial.

menghindar memiliki persentase yang sama (28\%).

Jenis kelamin laki-laki sebagian besar memiliki reaksi nyeri menghindar (33,33\%), sedangkan jenis kelamin perempuan sebagian besar memiliki reaksi nyeri tenang (30,95\%). Tidak terdapat hubungan yang signifikan antara jenis kelamin dengan reaksi nyeri ( $p$ value $=0,157 ; \alpha=0,05$ ). Anak usia prasekolah memiliki reaksi nyeri paling banyak yaitu menghindar (31,25\%), sedangkan anak usia sekolah, reaksi nyeri tenang dan emosi memiliki persentase yang sama $(28,57 \%)$. Tidak terdapat hubungan yang signifikan antara usia dengan reaksi nyeri ( $p$ value $=0,368 ; \alpha=0,05$ ). 
Sebagian besar anak yang takut memiliki reaksi nyeri menghindar $(37,77 \%)$ dan mayoritas anak yang tidak takut memiliki reaksi nyeri tenang (33,33\%). Terdapat hubungan yang signifikan antara ketakutan dengan reaksi nyeri ( $p$ value $=0,018 ; \alpha=$ 0,05). Sebagian besar anak dengan temperamen mudah memiliki reaksi nyeri yang sama antara reaksi tenang (28,57\%) dan reaksi menghindar $(28,57 \%)$, sedangkan anak dengan temperamen lambat memanas, mayoritas memiliki reaksi nyeri emosi (28,98\%). Tidak terdapat hubungan yang signifikan antara temperamen dengan reaksi nyeri ( $p$ value $=0,777 ; \alpha=0,05$ ).

Sebagian besar responden yang pernah mengalami nyeri sebelumnya memiliki reaksi nyeri emosi $(28,37 \%)$, sedangkan anak yang belum pernah mengalami nyeri sebelumnya, mayoritas memiliki reaksi nyeri menghindar (31,25\%). Tidak terdapat hubungan yang signifikan antara pengalaman nyeri sebelumnya dengan reaksi nyeri ( $p$ value = $0,929 ; \alpha=0,05)$.

Anak yang pernah terpapar nyeri memiliki reaksi nyeri yang sama besar antara reaksi emosi dan reaksi menghindar (28,57\%), sedangkan anak yang belum pernah terpapar nyeri sebelumnya memiliki reaksi nyeri yang sama besar antara reaksi emosi dan reaksi menghindar (27,42\%). Tidak terdapat hubungan yang signifikan antara paparan nyeri sebelumnya dengan reaksi nyeri ( $p$ value $=0,994 ; \alpha=0,05)$.

Tindakan pemasangan kateter intravena mayoritas anak memiliki reaksi nyeri berupa melindungi (50\%), tindakan pemberian obat injeksi, sebagian besar responden memiliki reaksi nyeri emosi $(29,78 \%)$, sedangkan tindakan pengambilan darah vena, sebagian besar memiliki reaksi nyeri menghindar (34,37\%). Tidak terdapat hubungan yang signifikan antara tindakan invasif dengan reaksi nyeri ( $p$ value $=0,445 ; \alpha=0,05)$. Sebagian besar anak dengan suku Betawi memiliki reaksi nyeri tenang (30,3\%). Mayoritas anak dengan suku Sunda, memiliki reaksi nyeri menghindar (46,66\%). Sebagian besar anak dengan suku Jawa memiliki reaksi nyeri emosi (29,73\%). Mayoritas anak dengan Suku minang, memiliki reaksi nyeri melindungi (40\%). Tidak terdapat hubungan yang signifikan antara suku bangsa dengan reaksi nyeri ( $p$ value $=0,703 ; \alpha=0,05$ )

Sebagian besar anak yang didampingi keluarga selain orang tua memiliki reaksi nyeri emosi. Anak yang tidak didampingi keluarga selain orang tua, sebagian besar memiliki reaksi nyeri tenang (32,5\%). Tidak terdapat hubungan yang signifikan antara kehadiran keluarga selain orang tua dengan reaksi nyeri $(p$ value $=0,060 ; \alpha=0,05$ ) 
Tabel 1.1 Pemodelan Multivariat (Uji Wald) Variabel Perilaku Ketakutan, Usia, Temperamen, dan Kehadiran Keluarga Selain Orang Tua

di RSUD Kota Bekasi, April-Mei 2015

\begin{tabular}{|c|c|c|c|c|c|c|}
\hline Reaksi nyeri & & Variabel & Wald & $\mathrm{p}$ value & $\operatorname{Exp}(B)$ & $\begin{array}{c}\text { 95\% Confident } \\
\text { Interval for Exp (B) }\end{array}$ \\
\hline \multirow{12}{*}{ Tenang } & Intercept & & 3.987 & .046 & & \\
\hline & \multirow{2}{*}{ Usia } & Prasekolah & 1.447 & .229 & .347 & $.062-.1944$ \\
\hline & & Sekolah & & & &.- . \\
\hline & \multirow{4}{*}{$\begin{array}{c}\text { Kehadiran } \\
\text { keluarga } \\
\text { selain orang } \\
\text { tua }\end{array}$} & Didampingi keluarga & 5.760 & .016 & .162 & $.036-.716$ \\
\hline & & selain orang tua & & & & \\
\hline & & Tidak didampingi & & . & . &.- . \\
\hline & & keluarga selain orang tua & & & & \\
\hline & \multirow{3}{*}{$\begin{array}{c}\text { Temperame } \\
n\end{array}$} & Temperamen mudah & .046 & .831 & 1.200 & $.225-6.387$ \\
\hline & & Temperamen lambat & . & . & . &.- . \\
\hline & & memanas & & & & \\
\hline & \multirow{2}{*}{ Ketakutan } & Takut & .318 & .573 & .602 & $.104-3.501$ \\
\hline & & Tidak takut & & & . & - \\
\hline \multirow{16}{*}{ Emosi } & Intercept & & .889 & .346 & & \\
\hline & \multirow{2}{*}{ Usia } & Prasekolah & 1.930 & .165 & .325 & $.066-1.587$ \\
\hline & & Sekolah & . & . & . &.- \\
\hline & \multirow{4}{*}{$\begin{array}{c}\text { Kehadiran } \\
\text { keluarga } \\
\text { selain orang } \\
\text { tua }\end{array}$} & Didampingi keluarga & .703 & .402 & .569 & $.152-2.125$ \\
\hline & & selain orang tua & & & & \\
\hline & & Tidak didampingi & & . & . &.- \\
\hline & & keluarga selain orang tua & & & & \\
\hline & \multirow{3}{*}{$\begin{array}{c}\text { Temperame } \\
n\end{array}$} & Temperamen mudah & .006 & .940 & .944 & $.212-4.207$ \\
\hline & & Temperamen lambat & . & . & . &. \\
\hline & & memanas & & & & \\
\hline & \multirow{2}{*}{ Ketakutan } & Takut & 1.723 & .189 & 2.851 & $.596-13.633$ \\
\hline & & Tidak takut & & . & . &.- \\
\hline & Intercept & & .690 & .406 & & \\
\hline & \multirow{2}{*}{ Usia } & Prasekolah & 2.017 & .156 & .307 & $.060-1.566$ \\
\hline & & Sekolah & . & . & . &.- \\
\hline & $\begin{array}{l}\text { Kehadiran } \\
\text { keluarga }\end{array}$ & $\begin{array}{l}\text { Didampingi keluarga } \\
\text { selain orang tua }\end{array}$ & 2.530 & .112 & .346 & $.094-1.279$ \\
\hline
\end{tabular}




\begin{tabular}{|c|c|c|c|c|c|c|}
\hline \multirow[t]{5}{*}{ Menghindar } & $\begin{array}{c}\text { selain orang } \\
\text { tua }\end{array}$ & $\begin{array}{l}\text { Tidak didampingi } \\
\text { keluarga selain orang tua }\end{array}$ & • & . & . &.- \\
\hline & \multirow{2}{*}{$\begin{array}{c}\text { Temperame } \\
\mathrm{n}\end{array}$} & Temperamen mudah & .038 & .845 & 1.157 & $.267-5.017$ \\
\hline & & $\begin{array}{l}\text { Temperamen lambat } \\
\text { memanas }\end{array}$ & . & . & . &.- . \\
\hline & \multirow{2}{*}{ Ketakutan } & Takut & 3.791 & .052 & 5.006 & $.989-25.329$ \\
\hline & & Tidak takut & & . & &.- . \\
\hline
\end{tabular}

The reference category is melindungi

Pada hasil analisis di atas, yang paling besar nilai exponen B nya adalah perilaku takut $(5,006)$, dapat diartikan bahwa perilaku takut merupakan variabel yang paling besar pengaruhnya terhadap reaksi nyeri dan

\section{Pembahasan}

Penelitian dari Petersen, Hagglof, dan Bergstrom (2009); Srouji, Ratnapalan, dan Schneeweiss (2010) menyatakan bahwa reaksi nyeri anak prasekolah yaitu menangis, berteriak, ekspresi verbal seperti "aduh", "aaow", sedangkan anak usia sekolah bereaksi terhadap nyeri dengan memegang sesuatu dengan erat dan mengalihkan perhatian dari sumber nyeri. Hal ini termasuk reaksi nyeri kategori emosi dan menghindar. Hasil penelitian dari Mathew (2003) menjelaskan bahwa perbedaan jenis kelamin antara anak laki-laki dan perempuan tidak terlalu berpengaruh terhadap respon nyeri karena hanya dipengaruhi oleh sensitivitas, pengalaman ekspresi, dan kondisi situasional yang mempengaruhi dan bagaimana anak menanggapi nyeri. Hasil penelitian dari Won (2006) dan Cohen (2008) menjelaskan bahwa peluang terjadinya reaksi nyeri kategori menghindar pada anak yang takut sebanyak 5,006 kali lebih besar dibandingkan anak yang tidak takut.

klien anak yang masuk rumah sakit akan muncul perasaan ketakutan karena rasa tidak aman dan tidak nyaman akibat nyeri. Hasil penelitian serupa juga dijelaskan oleh Meltzer et al. (2008) bahwa anak yang dirawat akan menjadi lebih cemas dan takut jika anak berpikir tentang nyeri, kekerasan, dan perpisahan dengan orang yang disayangi. Menurut Wong (2004) bahwa anak dengan tipe temperamen lambat memanas (slow to warm up) kurang dapat mengekspresikan nyeri daripada nyeri yang dialami sebenarnya. Anak dengan tipe temperamen tenang/mudah (tidak memberikan perlawanan dan bekerja sama) dapat menyebutkan skala nyeri yang dirasakan daripada anak dengan tipe temperamen sulit (menolak dan menyerang). Penelitian dari Schmitz, Vierhaus, dan Lohaus (2012) bahwa 
pengalaman nyeri sebelumnya berpengaruh pada persepsi seseorang tentang nyeri. Penelitian dari Noel, Chambers, McGrath, Klein, dan Stewart (2012) menjelaskan bahwa pengalaman nyeri sebelumnya pada klien anak berhubungan dengan rasa takut dari waktu ke waktu dan mempengaruhi pengalaman nyeri yang baru.

Menurut Teori Adaptasi Roy, manusia adalah adaptive system yang berupaya untuk selalu berinteraksi dan menyesuaikan diri dengan lingkungannya (Tomey \& Alligood, 2006). Semakin banyak seorang anak terpapar reaksi nyeri maka akan semakin banyak proses untuk menyesuaikan diri sehingga reaksi nyeri yang muncul pada awal anak dirawat dapat diadaptasi oleh dirinya seiring berjalannya waktu. Penelitian dari Gabriel (2007) menjelaskan bahwa tindakan invasif merupakan tindakan yang tidak nyaman bagi klien anak akibat nyeri yang dirasakan saat tindakan tersebut dilaksanakan. Hasil penelitian serupa juga dijelaskan oleh Mitchel dan Whitney (2001) bahwa injeksi atau pemberian suntikan merupakan salah satu tindakan invasif yang menyebabkan ketidaknyamanan, nyeri, dan takut pada klien anak.

Penelitian yang dilakukan oleh Prasetyo (2010) bahwa klien dengan suku Jawa mencoba untuk mengabaikan rasa sakit akibat nyeri dan hanya diam, menunjukkan sikap tabah, dan mencoba mengalihkan rasa sakit akibat nyeri melalui kegiatan keagamaan. Klien dengan suku Batak merespon nyeri dengan berteriak, menangis atau marah untuk mendapatkan perhatian dari orang lain sehingga menunjukkan ekspresif. Penelitian lain yang dilakukan oleh Baeyer dan Spagrud (2007) juga menjelaskan bahwa keyakinan dan nilai-nilai budaya mempengaruhi cara klien bereaksi terhadap nyeri. Penelitian dari Craig, Lilley, dan Gilbert (2006) bahwa kehadiran keluarga selain orang tua dapat mempengaruhi nyeri seseorang.

Pada penelitian ini, terjadi kerancuan antara nyeri dan tidak nyaman. Nyeri terjadi karena tindakan invasif yang melukai jaringan secara langsung seperti pemasangan kateter intravena, pengambilan darah melalui vena, dan tindakan invasif lain seperti pemasangan selang Naso Gastric Tube (NGT), sedangkan ketidaknyamanan terjadi karena pemberian obat injeksi melalui selang kateter intravena. Adanya kerancuan antara nyeri dan ketidaknyamanan menjadi keterbatasan dalam penelitian ini yang memungkinkan banyak faktor-faktor yang tidak berhubungan secara signifikan namun secara substansi berhubungan dengan timbulnya reaksi nyeri. Keterbatasan lain dalam penelitian ini adalah penggunaan rumus rule of thumb untuk besar sampel analisa multivariat, rumus rule 
of thumb ini tidak memakai $\alpha$ dan $\beta$ sehingga kesalahan tipe 1 dan kesalahan tipe 2 tidak diketahui. Keterbatasan lainnya dalam penelitian ini adalah variabel kehadiran keluarga selain orang tua sebaiknya diganti menggunakan variabel kehadiran orang tua saja.

Hasil penelitian ini dapat menjadi salah satu acuan dalam membuat intervensi keperawatan di rumah sakit sehingga perawat mengetahui intervensi yang dapat dilakukan pada anak terkait menurunkan reaksi nyeri menghindar. Pelayanan yang diberikan pada anak yang sering membuat anak takut sehingga muncul reaksi nyeri yang tidak sesuai dengan usia anak dapat diperbaiki.

\section{Kesimpulan}

Kesimpulan dari penelitian ini adalah reaksi nyeri terbagi empat kategori yaitu reaksi emosi dan menghindar masing-masing sebesar 28\%, reaksi melindungi sebanyak $23 \%$, dan reaksi tenang sebanyak $21 \%$; karakteristik anak pada penelitian ini antara lain usia anak yang rata-rata berada pada usia prasekolah, sebagian besar berjenis kelamin laki-laki, jumlah anak dengan perilaku takut sama dengan jumlah anak yang tidak takut, sebagian besar berada pada tipe temperamen lambat memanas, dan sebagian besar responden pernah mengalami nyeri sebelumnya.
Lebih dari separuh responden anak belum pernah terpapar nyeri sebelumnya, tindakan invasif yang paling banyak dilakukan adalah pemberian obat injeksi, sebagian besar responden anak memiliki suku Jawa, dan sebagian besar responden anak didampingi keluarga selain orang tua. Terdapat hubungan yang signifikan antara takut dengan reaksi nyeri, terjadinya takut kategori menghindar memiliki peluang sebanyak 5,006 kali lebih besar dibandingkan anak yang tidak takut.

\section{Saran}

Hasil penelitian ini dapat dijadikan sebagai data awal melakukan penelitian lebih lanjut di lingkup keperawatan anak. Penelitian lain yang dapat dilakukan berkaitan dengan hasil penelitian ini adalah lebih membedakan tindakan yang dilakukan pada anak yang melukai jaringan secara langsung sehingga menimbulkan nyeri atau tindakan yang menimbukan ketidaknyamanan saja tanpa menimbulkan reaksi nyeri yang berlebihan sehingga kerancuan yang terjadi dalam penelitian ini dapat diminimalkan.

\section{Ucapan Terima Kasih}

Saya ucapkan terima kasih kepada Ibu Ns. Fajar Tri Waluyanti, Sp.Kep, An., IBCLC, Ibu Ns.Happy Hayati, Sp.Kep, An, Ibu Dr. Nani Nurhaeni, S.Kp., MN, dan Ibu Dessie Wanda, S.Kp., MN selaku dosen Universitas Indonesia yang telah sabar memberikan bimbingan, 
masukan, dan arahan pada penulisan artikel

\section{Referensi}

Baeyer, C.L.V., \& Spagrud, L.J. (2007). Systematic review of observational (behavioral) measures of pain for children and adolescents aged 3 to 18 years. Pain, 127, 140-150. Doi: 10.1016/j.pain.2006.09.014.

Cohen, L.L. (2008). Behavioral approaches to anxiety and pain management for pediatric venous access. Pediatric, 45(7), 122-134. Diunduh dari http://pediatrics.aappublications.org/c ontent/122/Supplement3/S134.full.pdf

Craig, K.D., Lilley, C.M., \& Gilbert, C.A. (2006). Social barriers to optimal pain management in infants and children. Clin J Pain, 12(4), 232-242.

Czarnecki, M.L., Turner, H.N., Collins, P.M., Doellman, D., Darcy, M., Wrona, S., \& Reynolds, J. (2011). Procedural pain management: A position statement with clinical practice recommendations. Pain Management Nursing, 21(11), 1-17.

Gabriel, J. (2007). Infusion therapy part one: Minimising the risk. Nursing standard, 19(26), 41-48.

Hockenberry, M. J., \& Wilson, D. (2009). Wong's essentials of pediatric nursing. ( $8^{\text {th }}$ ed.). St. Louis: Elsevier Mosby.

Le Mone, P., \& Burke, K. (2008). Medical surgical nursing: Critical thinking in client care. ( $3^{\text {rd }}$ ed.). A Pearson Education Company.

Mathew, P.J. (2003). Assessment and management of pain in children review. $B M J, 45(5), 256-260$. Diunduh dari http://pmj.bmj.com

Meltzer, H., Vostanis, P., Dogra, N., Doos, L., Ford, T., \& Goodman, R . (2008). Children specific fear. Journal Compilation. Child: Care, health and development, 35(6), 781-789. Blackwell Publishing Ltd. ini.

Noel, M., Chambers, C.T., McGrath, P.J., Klein, R.M., \& Stewart, S.H. (2012). The influence of children's pain memories on subsequent pain experience. Pain, 115(16), 1563-1572.

Petersen, S., Hagglof, B.L., \& Bergstrom, E.I. (2009). Impaired health related quality of life in children with recurrent pain. Pediatrics, 124(4), 759-767.

Prasetyo, S.N. (2010). Konsep dan proses keperawatan nyeri. Yogyakarta: Graha IImu.

Schmitz, A.K., Vierhaus, M., \& Lohaus, A. (2012). Pain tolerance in children and adolescents: Sex differences and psychosocial influences on pain threshhold and endurance. European Journal of Pain, 10(2), 153-157.

Srouji, R., Ratnapalan, S., \& Schneeweiss, S. (2010). Parental holding and positioning to decrease IV stress in young children: A randomized controlled trial. Journal of Pediatric Nursing, 22(6), 257-263.

Supartini, Y. (2004). Buku ajar konsep dasar keperawatan anak. Jakarta: EGC.

Tomey, A.M., \& Alligood, R.M. (2006). Nursing science and their works. $\left(6^{\text {th }}\right.$ ed.) St.Louis: Mosby Elsevier.

Won, D. (2006). Effect of programmed information on coping behaviour and emotions of mother of young children undergoing IV procedures. Journal of Korean Academy of Nursing, 36(8), $1301-1307$.

Wong, D.L. (2004). Pedoman klinis keperawatan pediatrik. (M.Ester, Terjemahan). Jakarta: EGC. (Buku asli terbit tahun 1996). 